\title{
PELATIHAN PROSEDUR LABORATORIUM ANALISIS DNA
}

\author{
Dewi Indriyani Roslim*, Herman, Roza Elvyra, Nery Sofiyanti, \\ Ennie Chahyadi \\ Fakultas Matematika dan Ilmu Pengetahuan Alam, Universitas Riau \\ Kampus Bina Widya, Jl. HR Soebrantas Km 12,5, Panam, Pekanbaru 28293, Riau \\ email: dewiindriyaniroslim@gmail.com
}

\begin{abstract}
Currently, analysis based on DNA is one of the techniques for solving the problems such as paternity test, determining the identity of accident victims, natural disasters victims, and authentication of foods ingredients. But not everyone knows about the stages of DNA analysis laboratory procedures. The purpose of this workshop is to provide knowledgments about DNA analysis laboratory procedures. The training was attended by 30 participants from various universities and research centers in Riau Province. Workshop materials include DNA isolation of animal, plant and bacterial, electrophoresis, polymerase chain reaction (PCR), and visualization of DNA bands. Evaluation uses a questionnaire distributed to participants. Questionnaire analysis showed that workshop was very useful especially for beginners who want to be involved in DNA analysis activities in the laboratory.
\end{abstract}

Keywords: DNA isolation, Electrophoresis, laboratory procedure, PCR, workshop

\section{Abstrak}

Analisis berbasis DNA merupakan salah satu cara yang akhir-akhir ini sering dilakukan orang untuk menyelesaikan masalah seperti menentukan identitas korban kecelakaan atau korban bencana alam, pelaku tindak kriminal, dan kandungan jenis organisme pada suatu produk pangan. Namun belum semua orang paham mengenai tahapan prosedur laboratorium analisis DNA. Tujuan pelatihan ini adalah untuk memberikan pemahaman tentang prosedur laboratorium analisis DNA. Pelatihan diikuti oleh 30 peserta dari berbagai perguruan tinggi dan balai penelitian di Provinsi Riau. Materi pelatihan meliputi isolasi DNA hewan, tumbuhan, dan bakteri, elektroforesis, polymerase chain reaction (PCR), dan visualisasi pita DNA. Evaluasi menggunakan angket yang disebarkan kepada peserta pelatihan. Analisis angket menunjukkan bahwa pelatihan sangat bermanfaat terutama bagi pemula yang ingin berkecimpung dalam kegiatan analisis DNA di laboratorium.

Keywords: Elektroforesis, isolasi DNA, PCR, pelatihan, prosedur laboratorium

\section{PENDAHULUAN}

Analisis berbasis DNA merupakan salah satu cara yang akhir-akhir ini sering dilakukan orang untuk menyelesaikan masalah yang timbul di masyarakat. Kasus pertama yang diselesaikan menggunakan analisis berbasis DNA adalah masalah imigrasi (Gill et al. 1985; Saad 2005). Sementara itu, kasus akhir-akhir ini yang telah diselesaikan menggunakan analisis DNA diantaranya menentukan identitas korban kecelakaan pesawat Air Asia 8370, menentukan kandungan bahan pangan dalam suatu makanan, terutama untuk tujuan menentukan kehalalan produk makanan (Balai Besar POM 2010; Fahmi 2013). Atau di luar negeri, analisis DNA telah digunakan untuk menentukan kualitas dan keaslian suatu produk makanan dan minuman. Teknologi analisis DNA juga telah digunakan untuk merakit varietas tanaman unggul guna kesejahteraan 
manusia (Narayanan et al. 2011). Analisis DNA telah dimanfaatkan pada berbagai bidang kehidupan manusia, seperti bidang kedokteran untuk mengevaluasi transmisi tumor setelah transplantasi, paternity test, dan identifikasi spesimen patologi (Saad 2005).

Prosedur analisis berbasis DNA yang berkembang sampai saat ini meliputi isolasi DNA, elektroforesis, dan PCR (polymerase chain reaction) (Jeffreys et al. 1992). Isolasi DNA adalah mengambil DNA dari sampel berbagai organisme, misal dari daun tumbuhan, sel bakteri, darah atau otot hewan, rambut, dan kuku. Elektroforesis adalah memigrasikan partikel bermuatan, seperti asam nukleat (DNA dan RNA) dan protein, pada matriks berpori (gel agarose dan poliakrilamid) di bawah pengaruh medan listrik. Polymerase chain reaction adalah reaksi berantai menggunakan enzim polimerase.

Tujuan pelatihan ini adalah untuk memberikan pemahaman tentang prosedur laboratorium analisis DNA.

\section{METODE PENELITIAN}

Pelatihan dilakukan pada Kamis, 19 Juli 2018 di Laboratorium Genetika, Jurusan Biologi, FMIPA, Universitas Riau (UNRI). Pelatihan diikuti oleh 30 peserta yang terdiri dari dosen, pranata lab dan mahasiswa pascasarjana dari berbagai institusi, seperti Balitbang Teknologi Serat Tanaman Hutan, Universitas Islam Riau (UIR), Universitas Muhammadiyah Riau (UMRI), Universitas Islam Negeri Sutan Syarif Qasim (UIN SUSQA), Universitas Pasir Pangarayan (UPP), STIKES Hangtuah dan UNRI. Materi pelatihan meliputi isolasi DNA hewan (ikan dan kupu-kupu), tumbuhan (pandan, paku-pakuan, dan durik-durik), dan bakteri, elektroforesis, polymerase chain reaction ( $\mathrm{PCR})$, dan visualisasi pita DNA di atas lampu UV. Metode meliputi: ceramah, praktek, diskusi dan tanya jawab, serta penyebaran angket sebagai bentuk evaluasi terhadap kegiatan pelatihan dan untuk menentukan tingkat pemahaman peserta terhadap materi pelatihan. Angket terdiri dari tujuh pertanyaan (Tabel 1).

Tabel 1. Hasil analisis angket pelatihan

\begin{tabular}{|c|l|}
\hline No. & \multicolumn{1}{|c|}{ Komponen Pertanyaan } \\
\hline 1 & $\begin{array}{l}\text { Materi yang disajikan dapat } \\
\text { menambah wawasan saya tentang } \\
\text { prosedur laboratorium analisis } \\
\text { DNA }\end{array}$ \\
\hline 2 & Pelatihan cukup interaktif \\
\hline 3 & $\begin{array}{l}\text { Materi atau bahan pelatihan dapat } \\
\text { membantu saya dalam } \\
\text { meningkatkan wawasan tentang } \\
\text { prosedur laboratorium analisis } \\
\text { DNA }\end{array}$ \\
\hline 4 & $\begin{array}{l}\text { Setelah mengikuti pelatihan ini, } \\
\text { saya yakin dapat melakukan } \\
\text { analisis DNA }\end{array}$ \\
\hline 5 & $\begin{array}{l}\text { Kegiatan pelatihan ini dapat } \\
\text { meningkatkan kemampuan dan } \\
\text { keterampilan saya untuk } \\
\text { melakukan prosedur laboratorium } \\
\text { analisis DNA }\end{array}$ \\
\hline 6 & $\begin{array}{l}\text { Kegiatan pelatihan ini dapat } \\
\text { membantu saya untuk } \\
\text { meningkatkan profesionalisme }\end{array}$ \\
\hline 7 & $\begin{array}{l}\text { Ketersediaan sarana dan prasarana } \\
\text { selama pelatihan untuk peserta } \\
\text { sudah memadai }\end{array}$ \\
\hline
\end{tabular}

\section{HASIL DAN PEMBAHASAN}

Tim PPUPIK (Pengembangan Unit Produk Intelektual Kampus) Klinik Analisis DNA dari jurusan Biologi FMIPA Universitas Riau telah menyelenggarakan pelatihan berjudul "Prosedur Laboratorium Analisis DNA" pada hari Kamis 19 Juli 2018 di Laboratorium Genetika, Jurusan Biologi, FMIPA, UNRI. PPUPIK Klinik Analisis DNA adalah salah satu bentuk kegiatan pengabdian dosen berbasis ilmu pengetahuan dan teknologi yang diberi dukungan dana oleh Kemenristekdikti RI. Orientasi 
Klinik Analisis DNA adalah layanan jasa analisis DNA untuk berbagai tujuan, misalnya untuk keperluan identifikasi organisme yang berasal dari alam maupun produk pangan. Acara dibuka oleh Wakil Dekan 2 FMIPA UNRI, Dr. Elfizar, S.Si., M.Kom di gedung Dekanat FMIPA UNRI. (Gambar 1).

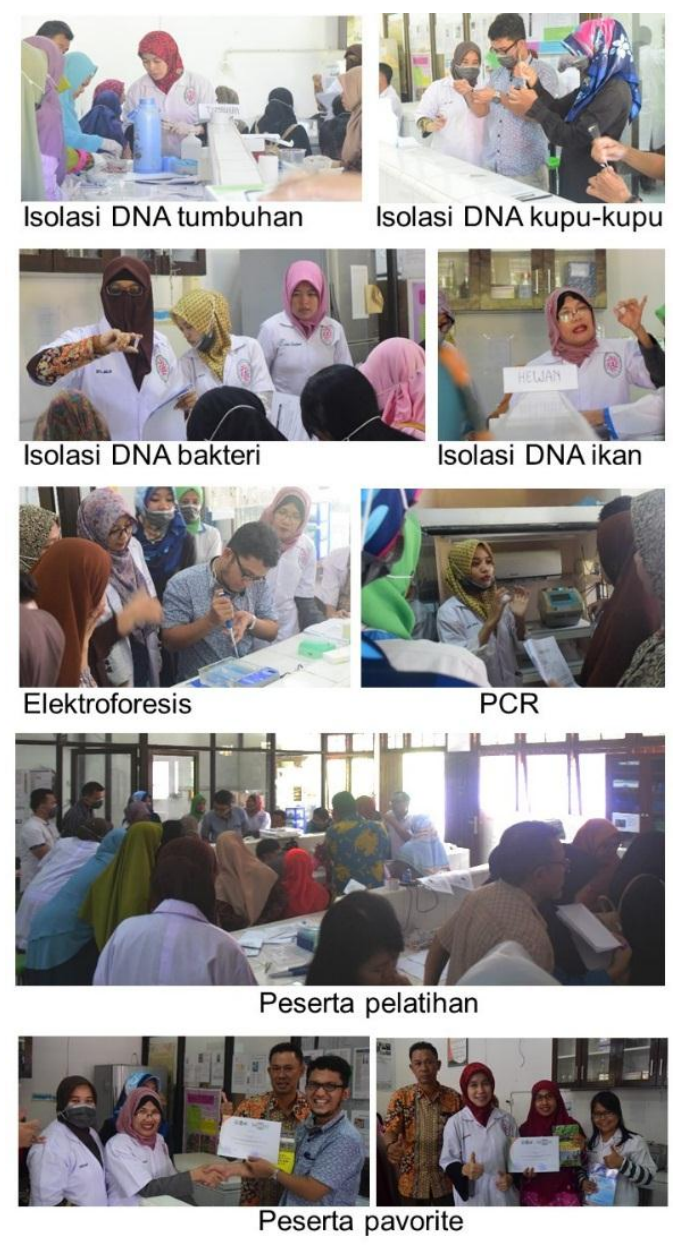

Gambar 1. Kegiatan pelatihan

Sebanyak $73,33 \%$ peserta sangat setuju dan $26,67 \%$ setuju bahwa materi yang disajikan selama pelatihan dapat menambah wawasan mereka tentang prosedur laboratorium analisis DNA (Gambar 2). Hasil ini menunjukkan bahwa materi yang disajikan dalam bentuk ceramah dan diskusi berhasil menanamkan pemahaman kepada peserta pelatihan.

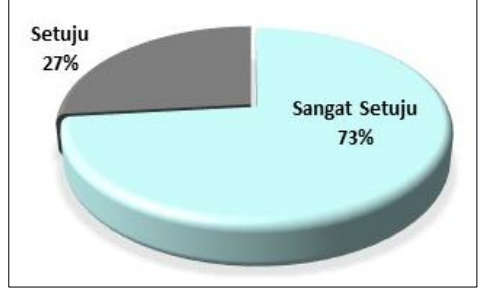

Gambar 2. Materi yang disajikan dapat menambah wawasan saya tentang prosedur laboratorium analisis DNA

Sebanyak 53\% sangat setuju dan $47 \%$ setuju bahwa pelatihan berlangsung cukup interaktif (Gambar 3). Pada saat praktek, instruktur memberikan teori tentang tahapan analisis DNA, yaitu isolasi DNA hewan, tumbuhan, dan bakteri, elektroforesis, dan PCR. Peserta secara aktif dan antusias berdiskusi secara bebas dan leluasa dengan instruktur. Instruktur memberikan jawaban yang cukup memuaskan kepada peserta.

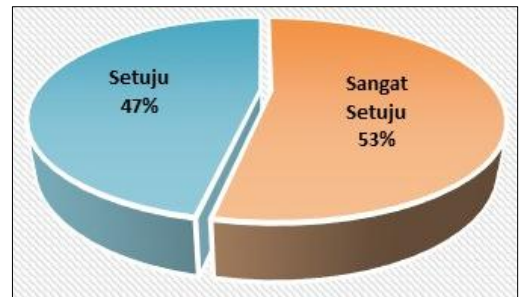

Gambar 3. Pelatihan cukup interaktif

Sebanyak $67 \%$ sangat setuju dan $33 \%$ setuju bahwa materi atau bahan pelatihan dapat membantu peserta dalam meningkatkan wawasan tentang prosedur laboratorium analisis DNA (Gambar 4). Hal ini dimungkinkan karena prosedur analisis DNA yang disajikan pada pelatihan adalah prosedur terbaru. Contoh, isolasi DNA yang disajikan saat pelatihan dilakukan menggunakan kit isolasi DNA yang lebih praktis, mudah dikerjakan oleh semua orang, dan cepat ( 2 jam). Berbeda dengan prosedur isolasi DNA secara konvensional yang membutuhkan waktu lama (satu atau dua hari) dan tidak praktis. Hal tersebut membuka wawasan peserta bahwa prosedur laboratorium 
analisis DNA sebenarnya dapat dilakukan dengan mudah, cepat, dan praktis. Contoh lain, proses elektroforesis dilakukan dalam waktu singkat 15 menit karena menggunakan aparatus elekroforesis terbaru. Jadi lamanya waktu elektroforesis bergantung kepada aparatus elektroforesis yang dipakai serta konsentrasi gel yang digunakan.

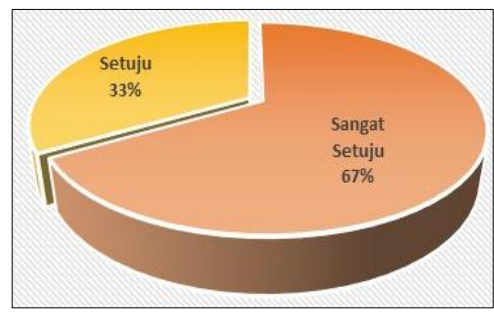

Gambar 4. Materi atau bahan pelatihan dapat membantu saya dalam meningkatkan wawasan tentang prosedur laboratorium analisis DNA

Sebanyak $43 \%$ sangat setuju dan $40 \%$ setuju bahwa setelah mengikuti pelatihan, peserta yakin dapat melakukan analisis DNA. Namun, 17\% peserta tidak yakin dapat melakukan analisis DNA sendiri (Gambar 5). Hal ini sangat bergantung kepada keyakinan peserta.

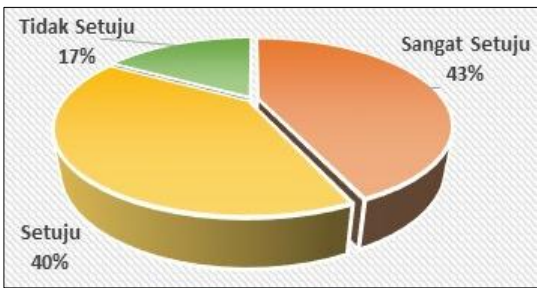

Gambar 5. Setelah mengikuti pelatihan ini, saya yakin dapat melakukan analisis DNA

Sebanyak $67 \%$ sangat setuju dan $33 \%$ setuju bahwa kegiatan pelatihan ini dapat meningkatkan kemampuan dan keterampilan peserta untuk melakukan prosedur laboratorium analisis DNA (Gambar 6). Hal dimungkinkan karena prosedur yang disajikan relatif mudah dan cepat untuk dipraktekan. Selain itu, instruktur juga memberikan trik-trik dan berbagi pengalaman selama mengenai prosedur laboratorium analisis DNA.
Contoh, apabila isolasi DNA menggunakan kit maka ikuti saja prosedur yang tertulis sesuai instruksi pabrik, dengan demikian akan diperoleh hasil yang memuaskan. Contoh lain, PCR menggunakan master mix PCR akan memudahkan peserta karena komposisi reaksi sudah optimum. Selain itu, gel untuk elektroforesis diberi pewarna pita DNA sebelum dituang ke cetakan gel untuk kemudahan dan kepraktisan.

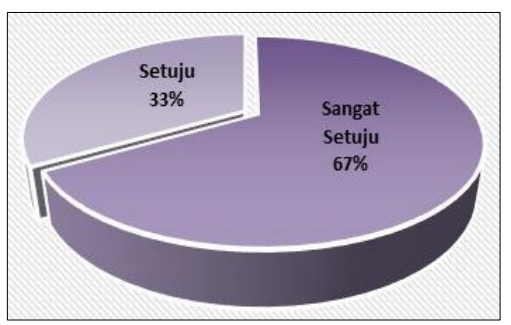

Gambar 6. Kegiatan pelatihan ini dapat meningkatkan kemampuan dan keterampilan saya untuk melakukan prosedur laboratorium analisis DNA

Sebanyak $40 \%$ sangat setuju dan $60 \%$ setuju bahwa kegiatan pelatihan ini dapat membantu peserta untuk meningkatkan profesionalisme (Gambar 7). Hal terutama karena peserta pelatihan sebagian besar adalah dosen dan atau peneliti.

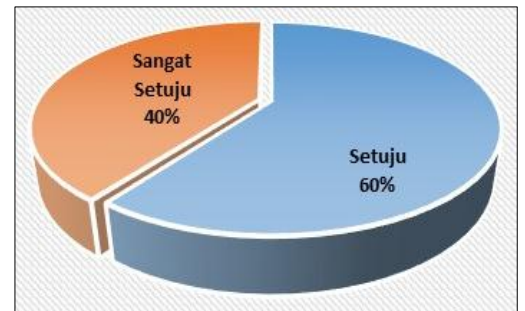

Gambar 7. Kegiatan pelatihan ini dapat membantu saya untuk meningkatkan profesionalisme

Sebanyak $43 \%$ sangat setuju dan $47 \%$ setuju bahwa ketersediaan sarana dan prasarana selama pelatihan untuk peserta sudah memadai. Sebanyak $10 \%$ peserta tidak setuju karena beberapa alat memang masih terbatas jumlahnya, seperti mikropipet dan aparatus elektroforesis (Gambar 8). Namun 
sarana dan prasarana tersebut sudah memadai bagi Tim PPUPIK Klinik Analisis DNA untuk melakukan layanan jasa analisis DNA. Selama ini, dengan sarana dan prasaran tersebut sudah berhasil dilayani sejumlah sampel dari beberapa konsumen yang berasal dari Riau, Sumatera Barat, dan Sulawesi Utara (Roslim et al., 2017).

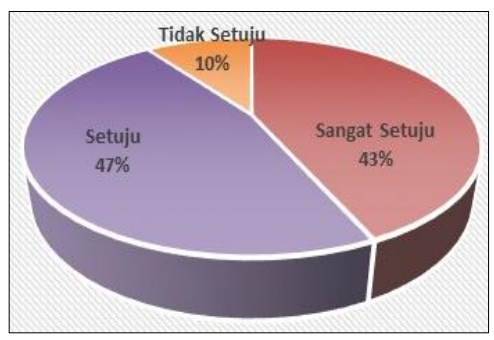

Gambar 8. Ketersediaan sarana dan prasarana selama pelatihan untuk peserta sudah memadai

\section{SIMPULAN}

Kegiatan pelatihan sebagai pengabdian kepada masyarakat oleh dosen Jurusan Biologi telah berhasil mentransfer ilmu terkait prosedur laboratorium analisis DNA. Secara keseluruhan analisis angket menunjukkan bahwa kegiatan pelatihan sangat bermanfaat terutama bagi pemula yang ingin berkecimpung dalam kegiatan analisis DNA di laboratorium.

\section{UCAPAN TERIMAKASIH}

Ucapan terima kasih kami sampaikan kepada Direktorat Riset dan Pengabdian Kepada Masyarakat (DRPM); Direktorat Jenderal Penguatan Riset dan Pengembangan; Kementerian Riset, Teknologi, dan Pendidikan Tinggi (Kemenristekdikti) Republik Indonesia, serta Lembaga Penelitian dan Pengabdian Kepada Masyarakat (LPPM) Universitas Riau yang telah mempercayakan kami mengelola dana Pengabdian Kepada Masyarakat PPUPIK tahun 2018 a.n. Dr. Dewi Indriyani Roslim.

\section{DAFTAR PUSTAKA}

[1] Balai Besar POM. 2010. Peningkatan kapasitas laboratorium dengan alat PCR (polymerase chain reaction) untuk uji kehalalan produk. Mataram: BPOM. [diakses 29 Maret 2015

http://www.pom.go.id/new/index.ph $\mathrm{p} /$ view/ berita/495/].

[2] Fahmi K. 2013. BPOM: Produk Nestle di Indonesia Steril DNA Kuda. [diakses 29 Maret 2015 http://www.lensaindonesia.com/201 3/02/23/bpom-produk-nestle-diindonesia-steril-dna-kuda.html].

[3] Gill P, Jeffreys AJ, Werrett DJ. 1985. Forensic application of DNA fingerprints. Nature 318: 577-579.

[4] Jeffreys AJ, Allen MJ, Hagelberg E, Sonnberg A. 1992. Identiǔcation of the skeletal remains of Josef Mengele by DNA analysis. Forensic Sci Int 56: 65-76.

[5] Narayanan NN, Ihemere U, Ellery C, Sayre RT. 2011. Overexpression of hydroxynitrile lyase in cassava roots elevates protein and free amino acids while reducing residual cyanogen levels. PLoS ONE 6(7): e21996.

doi:10.1371/journal.pone.0021996.

[6] Roslim DI, Herman, Elvyra R, Sofiyanti N, Chahyadi E. 2017. IbIKK Klinik Analisis DNA. Prosiding Konferensi Nasional PKM-CSR ke-3 tahun 2017. Surakarta, 19-21 Oktober 2017.

[7] Saad R. 2005. Discovery, development, and current application of DNA identitiy testing. BUMC Proceedings 18:130-133. 